\title{
Institute of Hydrology
}

\section{RESEARCH 1969}

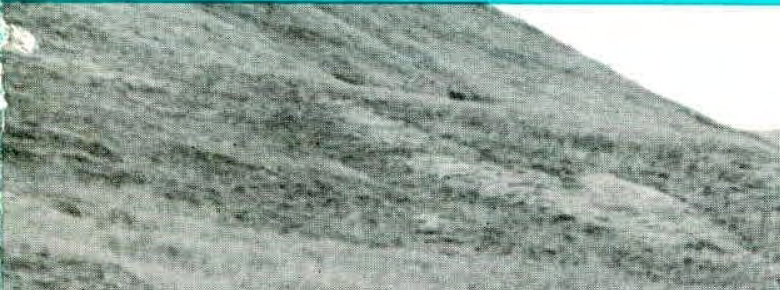

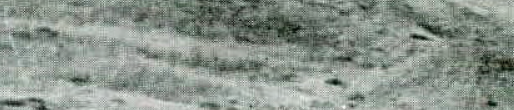

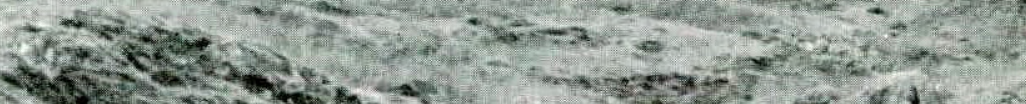

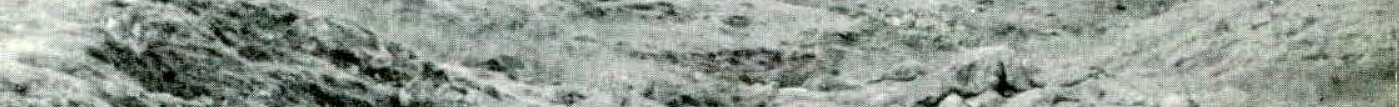

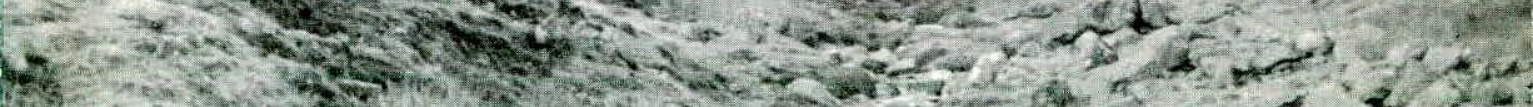

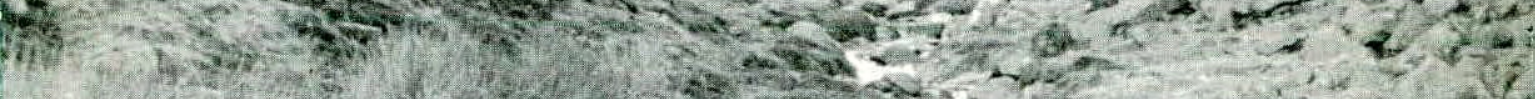
2.

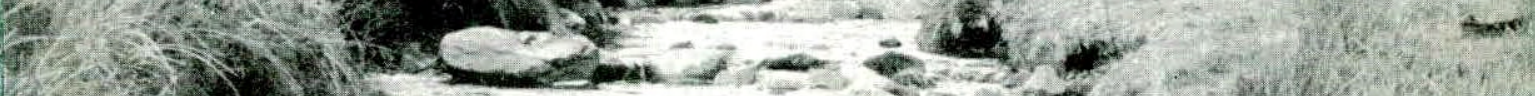

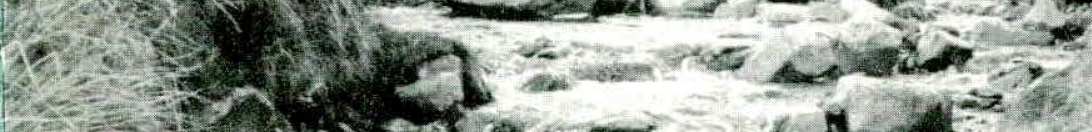

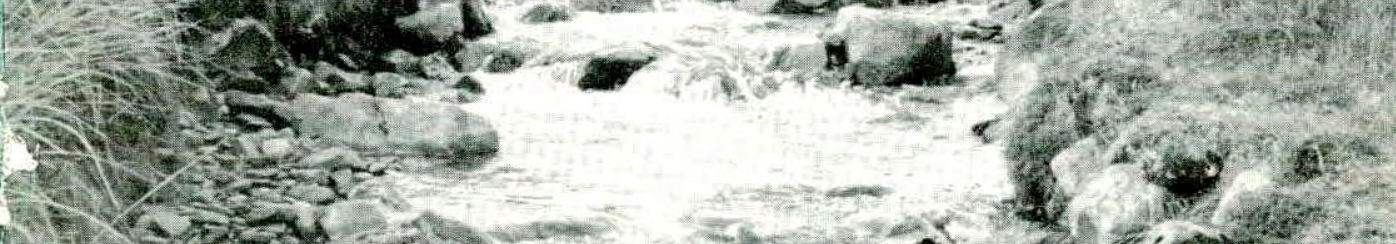

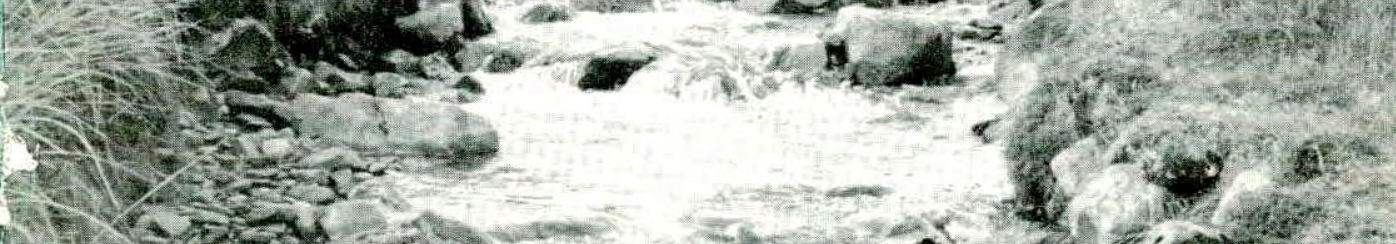

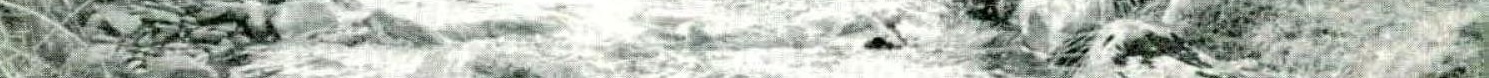

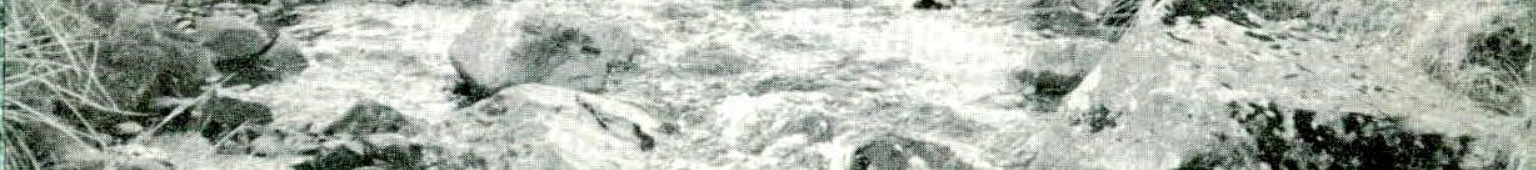

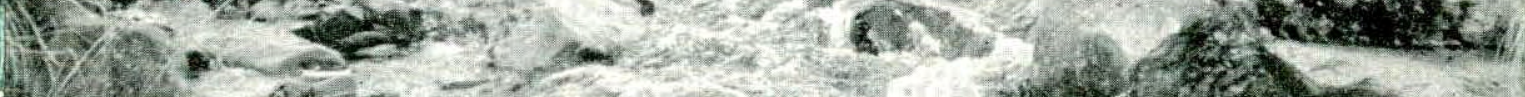

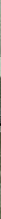


The Institute of Hydrology is a component body of the Natural Environment Research Council which itself is grant aided by the Department of Education and Science. Its programme of research is laid down by the Hydrology Committee of the Natural Environment Research Council, and its terms of reference include all phases of the hydrological cycle with special reference to the hydrological consequence of changes in land use in catchment areas.

All correspondence regarding the Institute and the Floods Team should be addressed to :

The Director, Institute of Hydrology, Howbery Park, Wallingford, Berkshire.

Telephone: Walıngforu 221 and Crowmarsh 4247

The Floods Team is situated at :

28 St. Mary's Street,

Wallingford,

Berkshire.

Telephone: Crowmarsh $\triangle$

The address of the Plynlir in Office of the Institute is:

Institute of Hydrology,

Dolydd,

Staylittle,

Llanbrynmair,

Montgomeryshire.

Telephone: Trefeglwys 652. 
NATURAL ENVIRONMENT RESEARCH COUNCIL

INSTITUTE OF HYDROLOGY

\section{Research 19}

HOWBERY PARK/WALLINGFORD/BERKSHIRE 



\section{CONTENTS OF THE 1969 RECORD OF RESEARCH}

STAFF OF THE INSTITUTE OF HYDROLOGY

Page No.

FOREWORD

iv

DIRECTOR'S REVIEW

vii

FLOOD STUDY PROJECT

Unit Hydrograph Studies

Flood Frequency Studies

Rainfall-Runoff Relationships

APPLIED HYDROLOGY

CATCHMENT AREA RESEARCH

Plynlimon

Coal Burn

Milton Keynes

East African Catchments

HYDROLOGICAL MODELS

WATER BALANCE MODELS

River Ray

River Cam

Cairngorms

South Georgia

MODEL STUDIES FOR FLOW FORECASTING 18

THETFORD PROJECT

SUBSURFACE HYDROLOGY

Soil Moisture Distribution and Storage Studies $\quad 26$

Unsaturated Flow Studies

Saturated Flow studies

Tritium Studies

INSTRUMENTATION AND COMPUTING

Data Logging and Automatic Weather Stations

Wallingford Probe

Groundwater Velocity Probe

Neutron Moisture Gauge Computer Programme

Quality Control and Data Processing 


\section{STAFF OF THE INSTITUTE OF HYDROLOGY}

J. S. G. McCulloch, Ph.D., F.Inst.P.

\section{APPLIED HYDROLOGY}

J. E. Nash, B.E., D.SC.

J. V. Sutcliffe, M.A., Ph.D.

D. T. Plinston, Ph.D.

P. W. Herbertson, M.Sc., D.I.C.

A. N. Mandeville, M.A. (at Imperial College, London)

J. R. Douglas, B.A.

\section{FLOODS TEAM}

R. C. Jones, B.Sc., D.I.C.

J. B. Miller, M.E., Ph.D.

M. J. Lowing, M.Sc., D.I.C.

C. Cunnane, B.E.

M. D. Newson, B.Sc.

M. A. Beran, B.Sc.

Miss E. A. Foster

Mrs. J. M. Haworth, B.Sc.

Mrs. J. K. Travell
Director

Consultant Hydrologist

Floods Team Leader

Engineering Hydrologist

Engineering Hydrologist

Mathematician

Assistant Hydrologist

Senior Hydrologist

Senior Hydrologist

Senior Hydrologist

Hydrologist

Hydrologist

Hydrologist

Assistant Hydrologist

Assistant Hydrologist

Programmer

\section{MATHEMATICS AND COMPUTING}

R. T. Clarke, M.A., M.Sc., Dip.Stat.

Statistician

B. L. Shaw, M.B.C.S.

Computer Manager

Miss A. Hill

Programmer

Miss A. Hitchings

Assistant Programmer

Miss J. M. Barnby

Mrs. L. J. Raynor

Trainee Programmer

Mrs. H. Gibbs

Machine Operator

Machine Operator

\section{HYDROMETEOROLOGY}

J. B. Stewart, B.Sc., D.I.C.

(Seconded from Meteorological Office)

Meteorologist

H. R. Oliver, M.Sc.

Mrs. S. A. Oliver, B.A.

Physicist/Meteorologist

Assistant Physicist

J. H. C. Gash, M.Sc.

Assistant Physicist/

Meteorologist

M. G. Briscoe

Experimental Assistant

N. J. Cox

Experimental Assistant

N. F. Cowell

Experimental Worker 


\section{Plant Physiology}

Staff directed by Professor A. J. Rutter of Imperial College under NERC Grant P. C. Robins, Ph.D. Plant Physiologist J. M. Roberts, B.SC.

Plant Physiologist

\section{SUBSURFACE HYDROLOGY}

\section{Groundwater}
A. G. P. Debney, B.Sc.
Hydrogeologist
P. C. Rowe, Ph.D., A.Inst.P.
Physicist
S. F. Pond, B.Sc.
Nuclear Physicist/
Geologist

R. I. Khan, M.Sc.

(Pakistan Atomic Energy Commission)

Hydrogeologist

D. S. Biggin

Assistant Hydrologist

P. C. Greenland

Experimental Assistant

\section{Soil Physics}

J. P. Bell, B.Sc.

C. W. O. Eeles

Miss H. Peck

P. M. Holdsworth

S. A. Boyle

P. T. Rosier

R. J. Raynor

B. J. Knapp, B.Sc.
Soil Physicist/Geologist

Soil Physicist

Assistant Soil Physicist

Soil Physics Assistant

Soil Physics Assistant

Soil Physics Assistant

Experimental Worker

Research Student

\section{INSTRUMENTS}

I. C. Strangeways, B.Sc., C.Eng., M.I.E.R.E.

Electronic Engineer

G. P. Brunsdon, C.Eng.. M.I.E.R.E.

A. J. B. Baty

A. C. Brown, B.Sc., Grad.I.E.R.E.

M. H. Rawlings

Electronic Engineer

Electronic Engineer

Electronic Engineer

Mrs. M. Turner

Electronic Engineer

Electronic Engineer

M. T. H. Key, M.Inst.M.C.

Mechanical Engineer

P. D. R. Andrews

Technical Officer

T. W. Markham

Instrument Craftsman

\section{PHYSICAL HYDROLOGY}

\section{Catchment Research}

J. C. Rodda, Ph.D., Dip.Ed. (Seconded to WMO, Geneva)

K. A. Edwards, Ph.D.

P. F. Smith, B.Sc.

Hydrologist/Geographer Hydrologist/Geographer Assistant Hydrologist 
S. W. Smith

(Seconded from Meteorological Office)

Senior Catchment Assistant

P. J. Hill

Catchment Assistant

I. G. Littlewood

(Seconded from Meteorological Office)

Catchment Assistant

Mrs. J. Avis

Catchment Assistant

Mrs. D. Bathe

R. H. Wyatt (Sandwich Course Student)

Catchment Assistant

Catchment Assistant

Based at Plynlimion

A. J. Bucknell

Senior Catchment Assistant

R. H. Holmes

Experimental Worker

Based in Kenya

J. R. Blackie, M.Sc,

(Seconded to Ministry of Overseas Development) Physicist/Hydrologist

H. M. Gunston (Seconded to EAAFRO)

Assistant Physicist

Committee, Library, Information

Miss A. J. Smith, B.Sc.

Geographer

B. C. Kennedy, B.A.

Geographer

\section{ADMINISTRATION}

\section{A. S. Norquay}

Miss M. P. Saxton

Mrs. C. Little

F. W. Freeman

Mrs. G. E. Lamb

Miss M. R. E. Kearsley

Mrs. R. H. Rumsby

Mrs. A. W. Wallington
A. H. Thomas
J. Perry Taylor
R. W. Railton

Higher Executive Officer (Station Secretary)

Executive Officer

Clerical Officer

Clerical Officer

Clerical Officer

Personal Secretary

Shorthand Typist

Shorthand Typist

Transport Officer

Driver

Storekeeper 


\section{FOREWORD}

It is evident to all, and especially to those who live near our larger rivers, that floods following heavy rain in catchments have become a more serious problem than hitherto. How far this can be attributed to changes in land use, such as the provision of more impermeable surfaces for roads and buildings, is uncertain, but clearly such environmental variations must be considered as a possible major factor in a highly complex situation. In June 1968 the Institute of Hydrology was honoured by a visit from the Secretary of State for Education and Science who, as the Minister responsible for the Natural Environment Research Council, announced that the Institute would undertake, as a matter of high priority, an investigation into floods in the United Kingdom on lines recommended by the Institution of Civil Engineers in its valuable report of 1967.

This decision, coming so soon after the opening of the Institute, has presented the Director with some formidable problems of rearrangement of programmes and recruitment and deployment of staff. Some disturbance is inevitable, but personally I welcome the decision as a challenge to skill and inventiveness which, if successfully overcome, will not only establish the reputation of the Institute but will add greatly to the welfare and happiness of our people.

The activities of the Institute in this critical year are set out frankly in this Report. It includes some disappointments as well as successes, but readers should be reminded that when the Natural Environment Research Council was constituted in June 1965 all that was under its control was a nucleus in the shape of the Hydrological Research Unit, with a total staff of seven. The Institute was set up formally as a component body of the Natural Environment Research Council in April 1968 , so that at the time of writing this Foreword it is not yet two years old. However, despite difficulties in recruiting suitably qualified staff (for hydrology is not yet a popular subject in British universities) and in creating the necessary facilities, a great deal has been done, including a major contribution to hydrological instrumentation in the form of the Wallingford Neutron Probe for soil moisture determinations.

As a country we are blessed (the word is used advisedly) with an abundant and never failing rainfall, but although we may be assured of the income side of the balance sheet there are formidable problems of water location, storage and distribution, and of the effects of environmental factors, on the expenditure side. At the final stage these problems are the concern of the statutory bodies $r \in$ sponsible for water supplies, 
but it is the prime duty of the Institute to establish and expand the basic science on which water engineers must rely. In the brief time that has elapsed since the Natural Environment Research Council came into being, a promising start has been made in this difficult field, and I have confidence that with the enthusiasm and devotion to duty shown by the Director and his staff we may expect continued progress.

O. G. SUTTON

Chairman of the Hydrology Committee of the Natural Environment Research Council 


\section{DIRECTOR'S REVIEW OF THE PERIOD 1st APRIL 1969 TO 31st MARCH 1970}

The year 1969 has been one of change for the Institute. The importance of the Floods Project has necessitated transfer of staff and effort from other parts of the Institute's programme. Dr. J. V. Sutcliffe was appointed leader of the Floods Team in October, the staff has been built up rapidly, additional premises have been rented in Wallingford and a three year programme drawn up, approved and initiated. Inevitably the balance of the Institute's work has suffered and this has necessitated a complete review of its structure. The aim is to build up the support staff to increase efficiency and at the same time to achieve a more rational organisation of activities commensurate with the growing responsibilities of the Institute. These now include the servicing of certain sub-committees of the Hydrology Committee of the Natural Environment Research Council, the effort needed to provide the scientific secretariat of the British Committee for the International Hydrological Decade and the increasing involvement of the Institute in international affairs in its own right. The Institute, in collaboration with headquarters staff of the Natural Environment Research Council, has also produced a survey of United Kingdom Research in Hydrology 1965-1970 which was presented to the IHD Mid Decade Conference. This report, updated and revised, will be presented to the World Water Balance Symposium at Reading in July.

With such a wide programme of new work at the Institute this year, inconsistencies in progress have been inevitable. However, substantial advances have been made, the highlights being in Instrumentation and the Thetford Project. A considerable amount of data from the catchment experiments has now been assembled on magnetic tape and quality control programmes are fully operational. Progress has been made in developing more realistic models of catchment behaviour.

During the year members of staff have been involved in a number of international meetings and in studies and projects in overseas countries. The Director attended the IHD Mid Decade Conference as Secretary of the British IHD Committee. Dr. Sutcliffe took part in a meeting of the UNESCO/WMO Working Group in Geneva on the International Glossary of Hydrology, and Mr. Herbertson accompanied Dr. Sutcliffe on a visit to Abu Dhabi for a survey of the water resources. Dr. Rodda spent the year as a consultant to the Division of Hydrometeorology of WMO in Geneva and subsequently attended a WMOCAgM Working Group meeting on Assessment of Drought. A paper was presented by Mr. Bell to the RILEM International Symposium on Radiometric Methods and Instruments for the Determination of Density and Moisture of Building 
Materials and Soils, at Brno, while Mr. Debney and Mr. Pond attended the Symposium on the Use of Isotopes in Hydrology at the International Atomic Energy Agency in Vienna. Mr. Debney also spent two weeks in Botswana in connection with a water resources survey. The Royal Geographical Society Expedition to South Turkana in Kenya had Dr. Plinston as one of its members and he spent some additional time in Kenya with Mr. Eeles, Mr. Mandeville and Miss Hill as part of the joint East African Agriculture and Forestry Research Organisation/Institute of Hydrology catchment research programme. Dr. Plinston also visited Bangkok in connection with the Mekong Basin Project. Several informal scientific meetings, organised by the Institute during the year, included such subjects as micrometeorology of forests, raingauge performance, hydrological instrumentation for network applications and continuous dilution gauging for streamflow measurement.

Despite the difficulties that have faced the Institute during the year the prospect for continuing scientific progress appears to be good. An increasing contribution to national and international hydrological research seems assured and, at the same time, the Institute is likely to play a greater part in applied and ad hoc studies both at home and overseas.

This report is presented as an account of a series of major projects, rather than an account of the work of the various sections into which the Institute is divided. In view of the participation of most sections in each project this avoids unnecessary duplication in the report. 


\section{FLOOD STUDY PROJECT}

A short-term investigation by the Institute into the magnitude and frequency of floods in the United Kingdom, along the lines recommended by the Institution of Civil Engineers, was announced during the visit of the Secretary of State for Education and Science on 19th July 1968. Recruitment of the Team has taken some time, but following the appointment of the Floods Team Leader in October 1969 the staff has built up speedily and new premises have been acquired, furnished and equipped at 28 St. Mary's Street, Wallingford. A three-year programme has been drawn up and approved by the Steering Committee. Planning was aided by a pilot study on the records of one area thus enabling a more realistic assessment to be made of the availability of data and of the work required in their assembly and appraisal. Contrary to the I.C.E. Committee's first impression, it is now thought less likely that a quantity of unpublished records is available for study, though the appraisal of historical records will nevertheless be a major task. The microfilming of water level charts has begun and a pencil follower with supporting software is being used to digitise these analogue data.

A series of preliminary contacts with River Authorities has been established and the preparation of basic data for each Authority initiated. The programme of studies comprises three main topics: unit hydrograph studies, flood frequency studies and rainfall-runoff relationships.

\section{Unit Hydrograph Studies}

Unit hydrographs are to be derived from a number of storms and associated river flows on each of a number of basins. As a preliminary step for selection of events for these and other studies, an annual hydrograph of daily mean flow for each station-year of record from gauging stations in the United Kingdom is to be produced. To this end, investigations have been made, in consultation with the Water Resources Board, into the most suitable methods of data preparation and handling. Though a three-year programme of work for the unit hydrograph studies has been prepared, development of the techniques to be used will continue simultaneously with the collection of data. A pilot unit hydrograph study on the records from the River Ray at Grendon Underwood was designed to test the constancy of the derived unit hydrographs and to study the relationship between their variation, if any, and the possible causes. The variability of the derived unit hydrograph was not clearly related to any observable causative factors, though uncorrected time to peak was found to depend on the duration of rainfall and the time taken before surface runoff occurred. This preliminary 
exercise suggested that it will be as important to study a number of storms as a number of basins.

\section{Flood Frequency Studies}

As a preliminary work for the proposed flood frequency analysis, earlier studies of the methods of deriving the frequency of distribution from a single annual maximum series were followed by a study of a method of deriving a distribution of annual maximum floods using more than one event per year. This implies a probability model in which certain assumptions lead to a Poisson distribution of the number of 'hazard events' above a given threshold in each year, and an exponential distribution of the magnitude of these events. The combination of these two distributions leads to the double exponential distribution for the annual maxima, but enables the parameters to be estimated simply by maximum likelihood analysis of several events per year. An expression for the standard error of the T-year flood derived by this method was obtained, and methods for testing the applicability of the model were demonstrated. This study led to the decision that it was necessary to collect data from more than one event per year from all available stations, in order that both methods of analysis would be available. Other background studies have been completed and a programme of work to be carried out during the flood frequency investigation was also prepared.

\section{Rainfall-Runoff Relationships}

This can be described as a three-fold attempt to use the techniques of flow forecasting:

(i) to augment river discharge records by relating runoff to other hydrological and meteorological records,

(ii) to select the significant physical parameters of the catchment and to estimate their value,

(iii) to provide indices of extreme flood runoff - i.e. estimates which while not numerically precise, would represent a regional trend of flood potential.

Preliminary work has concerned the first and third of these. When faced with a short period of record, say 10 years, at a particular gauging site, it is a common practice to extend the record by correlation with a longer period of record, say 25 years, at a nearby site. However, an analytical result has shown that, with a correlation coefficient of 0.6 or less between the data from the two stations, an estimate of a flood of large return period can be made with greater confidence from the shorter record of original data than from the longer simulated record. This result is to be checked with synthetic data. 
Rainfall of the same probability of occurrence as the floods under study has commonly been used as a climatic index for regional flood analysis. It is considered that a better index should be rainfall less soil moisture deficit. A pilot study to test the usefulness of this variable is using data, provided by the Meteorological Office, from six stations in England and from a denser network over the Trent catchment. Suitable distributions and methods of estimating their parameters, are being examined for rainfall $(R)$ and soil moisture deficit (SMD) separately. It is hoped that an estimate of R - SMD of a given probability can be expressed in terms of the parameters of these separate distributions. For the SMD distribution, particular attention has been paid to the data sampling interval necessary for the definition of the distribution. 


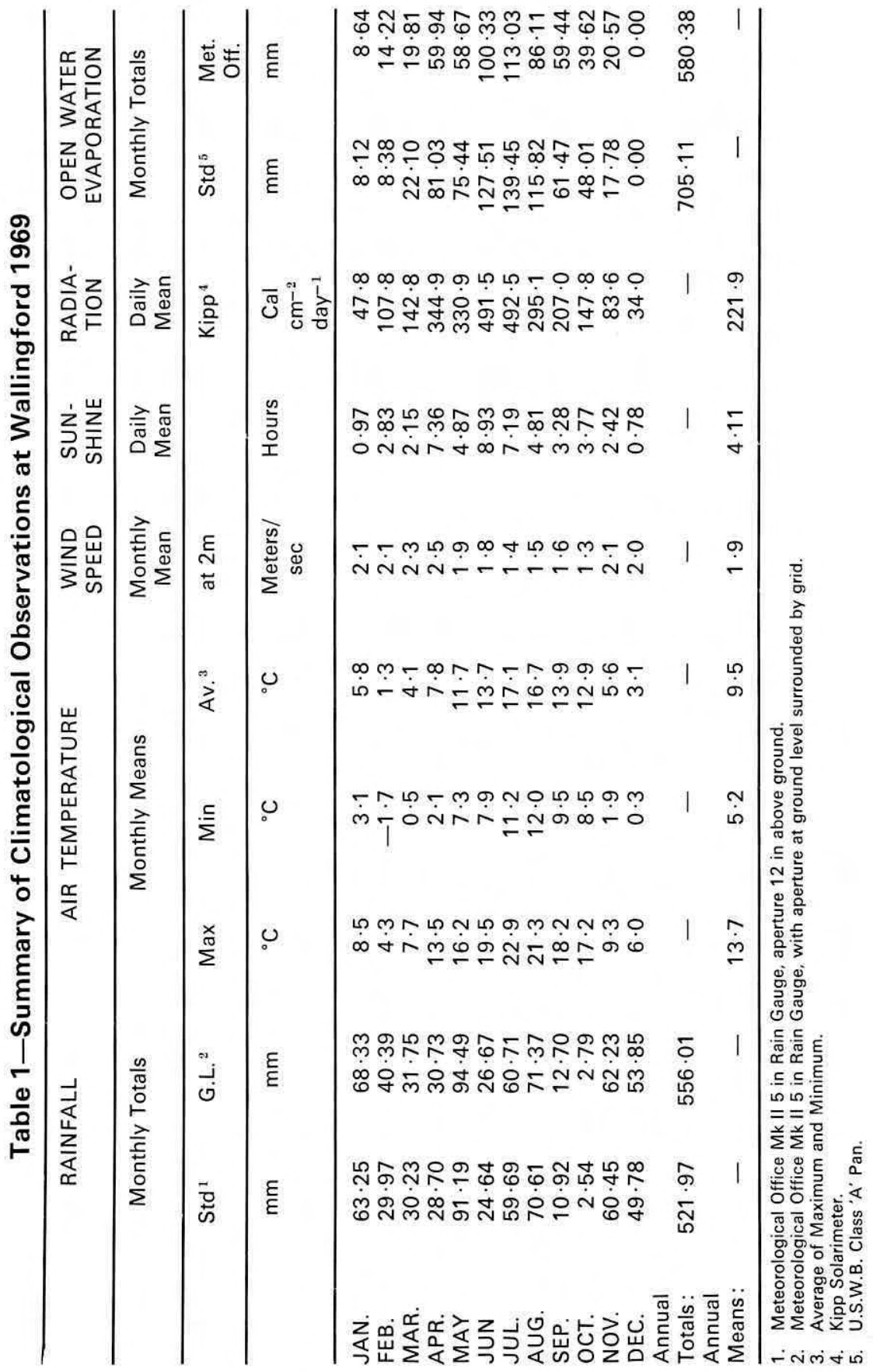




\section{APPLIED HYDROLOGY}

A visit was made to Abu Dhabi, the largest of the Trucial States on the southern shore of the Arabian Gulf, to study the water resources of the Al Ayn area. As there is groundwater but no surface water in this area of Abu Dhabi territory, the source of the groundwater was studied in the mountains of Muscat and Oman to the east. Reconnaissance showed a number of streams flowing off the mountains, supplying villages at the foot of the mountains, and recharging the groundwater resources. The total water use of the date gardens of these villages was estimated by considering potential evaporation and this was expressed as depth of runoff from each catchment. A relationship was found between catchment area and the irrigated area supplied with water by each stream. Three gauging sites were selected and surveyed, and designs have been prepared for proposed gauging structures.

The Institute again collaborated with the Royal Geographical Society expedition to South Turkana, a region of Northern Kenya. The results of the previous field season were analysed and further records were collected.

Two groundwater studies were made as part of water resources investigations being carried out in Botswana. In the first the groundwater resources of a series of dolomite and quartzite aquifers were examined as sources of supply for a township in southern Botswana. The second study was concerned with the feasibility of obtaining short term water supplies from river bed sands in an ephemeral stream in the north of the country.

The study being undertaken on behalf of the Water Resources Board on the optimum sampling interval for river level measurements by punched tape recorder, was continued using data from the River Ray catchment. Some of the results obtained, using 15 minute to 8 hour intervals, were described in a discussion at the Loughborough Symposium on River Gauging. Data have also been obtained from the Water Resources Board for various catchments, chosen to give a good range of size, rainfall, altitude and geology. It is hoped to relate the optimum sampling interval to some or all of these parameters. As these data were not obtained from research catchments, a considerable amount of preliminary processing and editing has had to be undertaken. 


\section{CATCHMENT AREA RESEARCH INTO THE EFFECTS OF CHANGES IN LAND USE ON THE HYDROLOGICAL CYCLE}

A major part of the work of the Institute has been directed towards determining the effect of a change in land use on the various parts of the hydrological cycle. In relation to the steadily increasing demand for water, it is important for land use planners to have information on the water use of different vegetational complexes. At the same time, if a change in the existing land use is envisaged, it is essential to know the hydrological changes that will follow in terms of volume of runoff and its distribution in time.

Catchment research offers virtually the only method of measuring water use from natural areas which are inevitably heterogeneous in topography, soil type, drainage density and vegetative cover. Comparative studies of adjacent catchments, or of the same catchment before and after a change in land use, are a means of assessing the hydrological effects of such a change. The Institute was charged with conducting long term experiments of this nature under its initial research programme laid down by the Natural Environment Research Council. Several have been started, both in the United Kingdom and overseas, and more are in preparation.

The major changes in land use in this country are associated with afforestation and urbanisation. Afforestation is mainly centred in upland areas which are also catchments for water supply and river regulation reservoirs. Information is required, therefore, both on water use in relation to the type of vegetation which preceded the forest and on the effect of the forest on peak runoff downstream. In the latter context, the pre-planting practices of deep ploughing and draining may be more important than the presence of the trees.

The effects of urbanisation are most apparent in relation to runoff volume and distribution, although the change in water quality or nutrient balance of an area may have far reaching biological consequences. The Institute's contribution to European Conservation Year is centred around a combined research project into both these features of urbanisation.

\section{Plynlimon}

In the Plynlimon experiment the forested headwaters of the River Severn are being compared with the adjacent grassland headwaters of the River Wye. Both catchments are similar in size, geology and physiography and are instrumented with stream gauging structures, rainfall recorders, climatological stations and access tubes (for the 
neutron scattering method of soil moisture measurement). In addition, the experiment serves as an outdoor laboratory within which projects in physical hydrology and other disciplines may be carried out. These include work on precipitation and soil moisture sampling, on the nutrient balance of the two catchments (University College of Wales, Aberystwyth, Department of Agricultural Botany), soil water movement (University of Reading, Department of Geography) and groundwater. Rain and river water are also being sampled for radioactive fallout from nuclear explosions on behalf of the Radiochemical Inspectorate of the Ministry of Housing and Local Government.

The basic data collection period is only partially completed for much of the experimental programme. Analysis of the records from the complex instrument networks has posed particular data processing problems and testing of the validity of the sampling networks has been delayed pending the completion of revised software.

Preliminary analysis of the soil moisture records indicates that soil moisture changes are very small over large areas of the catchment but that further systematic sampling of slope elements is required to determine the representativeness of the point measurements. The high rainfall and steep topography of the Plynlimon area have produced, from the shaly mudstone parent material, catenary sequences of variably podzolised colluvial soils and boulder clays. The Wallingford Probes are being used to investigate the relationship between such factors as slope angle, slope element, aspect and soil type on the one hand, and moisture content and variability on the other. If the relationship is found to be significant, it will be used to define soil moisture domains, enabling rationalisation of network design and improved storage estimates. Two networks of access tubes were installed at the start of the experiment; one consisted of a series of lines sampling typical slope catenas and the second was randomly placed to sample the flatter areas on the higher slopes. Results from the random network have been difficult to interpret and it is now thought that more information will be derived from the systematic network (Bell and McCulloch, 1969).

The installation of the full raingauge network at ground level and canopy level has taken a considerable time. Records from the gauges at the highest altitude show that annual rainfall may be as high as $3000 \mathrm{~mm}$. Its distribution throughout the catchment is largely determined by altitude, and statistical techniques (trend surface analysis, analysis of variance) are being applied to determine the essential features of the rainfall pattern.

The study of subsurface flow in various layers of a typical Plynlimon 


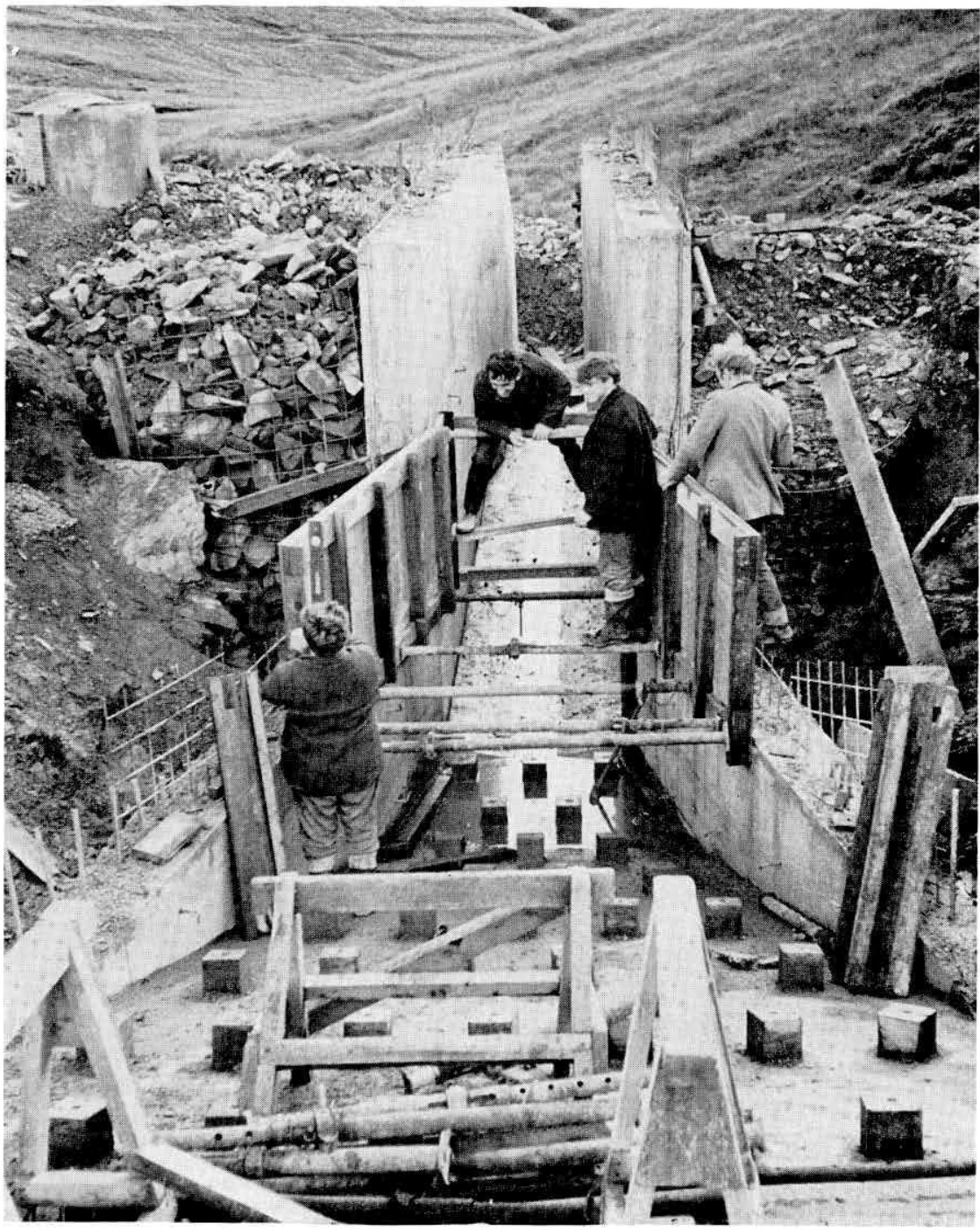

Figure 1 Steep stream gauging structure under construction at Plynlimon 
soil profile has been continued by Mr. B. Knapp in preparation for a Ph.D. thesis to be submitted to the University of Reading. This research topic is being expanded and linked with the subsurface hydrology research programme of the Institute. A field study of the subsurface components of the runoff hydrograph has begun in the area. Detailed mapping of the solid geology, the superficial deposits, the thickness of peat and surface runoff channels has been completed in the Tanllwyth (forested) and the lago (grassland) sub-catchments.

The Plynlimon experiment has required the development of a number of special instruments and structures which have been described in previous Records of Research. After testing in severe winter conditions, the 32-day raingauge (Record of Research 1967, p 36) has proved to be satisfactory only when the mechanism is placed below ground, and even then some failures occur. These are caused in general by moisture in the clock and the question of changing the whole clock unit for a sealed type is being considered. Nevertheless, these gauges have proved most useful for an experiment where other conventional gauges would have been unsuitable, and thus they have enabled a large amount of daily rainfall data to be gathered with comparatively little effort.

The 7-day recording anemometer (Key, 1965) has been used to obtain daily run-of-wind at a remote site which could only be visited weekly. It has performed well although occasional losses of records have occurred, due to minor electrical component fatigue in the recorder and the need for routine maintenance on the associated standard anemometer. Once again, as an interim device pending the appearance of inexpensive battery operated loggers, it has been invaluable in recording information which might otherwise have been unobtainable.

Of the six steep-stream gauging structures (Record of Research 1966, p 36) planned in the Plynlimon area, those on the Hafren, Tanllwyth and lago streams (Fig. 1) have been completed and the Wye flume was nearly complete at the end of the year. The experience gained on the three completed structures has led to modifications in the method of hydraulic design and the rearrangement of the energy dissipating baffles in the ramp. Work has already begun on the final two structures, the Cyff and Hore, which should be completed by the end of 1970 . To provide an accurate reference of water level in these structures, vernier manometers (Fig. 2) have been designed and manufactured at the Institute.

\section{Coal Burn}

A second experiment into the effects of afforestation is in progress on the Coal Burn, a tributary of the River Irthing, where the Cumberland 
River Authority maintain a small instrumented catchment (152 hectares) on the edge of the Kielder Forest. The Forestry Commission has delayed its deep ploughing and planting operations there while the Institute records rainfall, evaporation and runoff from the unforested grassland. When the ploughing operations take place sometime in 1972, their effect on runoff will be observed. The results will be relevant to the Forestry Commission's drainage practices in general, although, in a strict sense, they will apply only to the climatic regime, physical

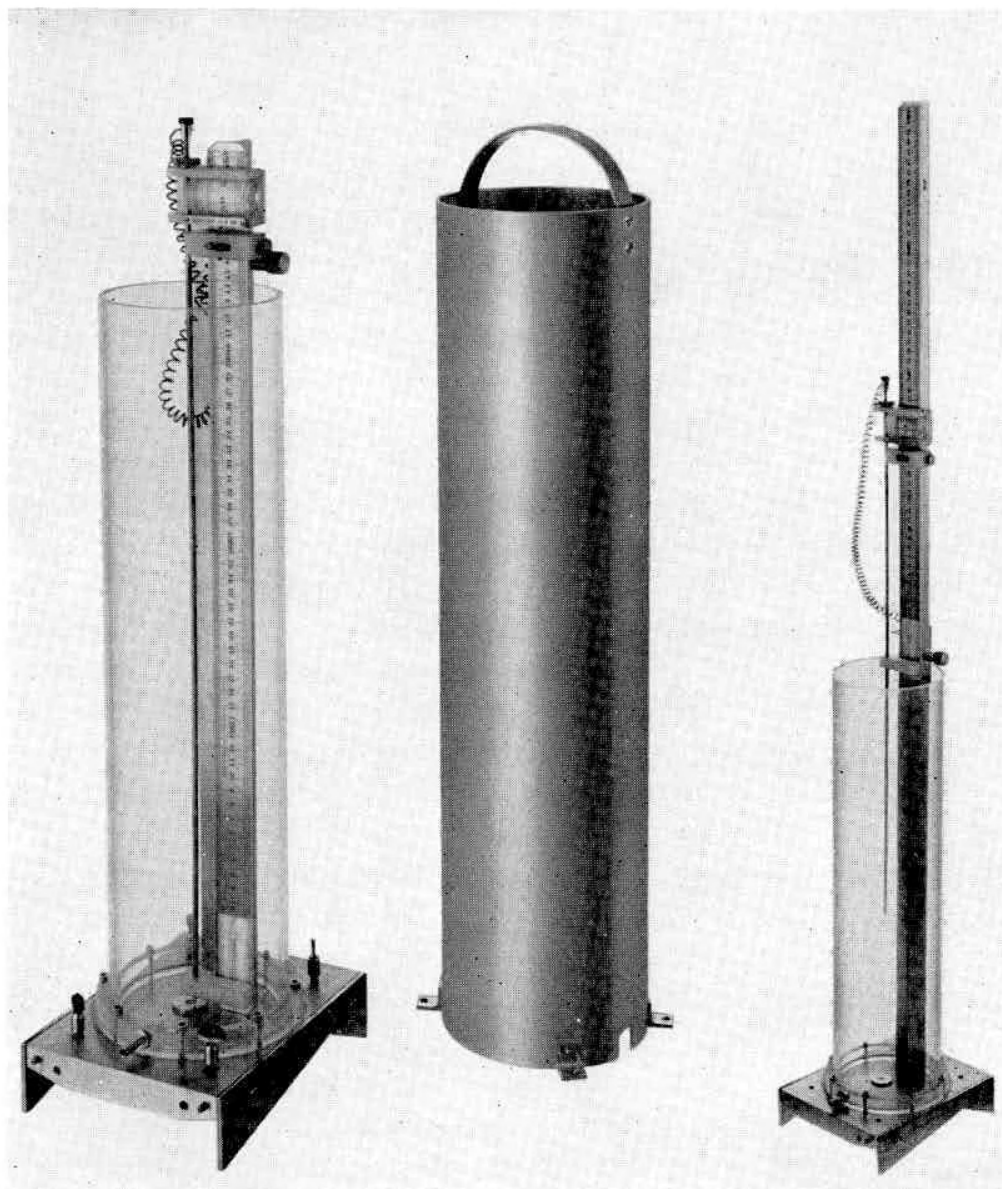

Figure 2 Vernier manometer

On the left is the instrument.

In the centre is the robust shield tube which covers the assembly in transit.

On the right is the manometer in use on a Crump gauging weir; the profile of the base may be adapted to fit other types of weir or flume. 


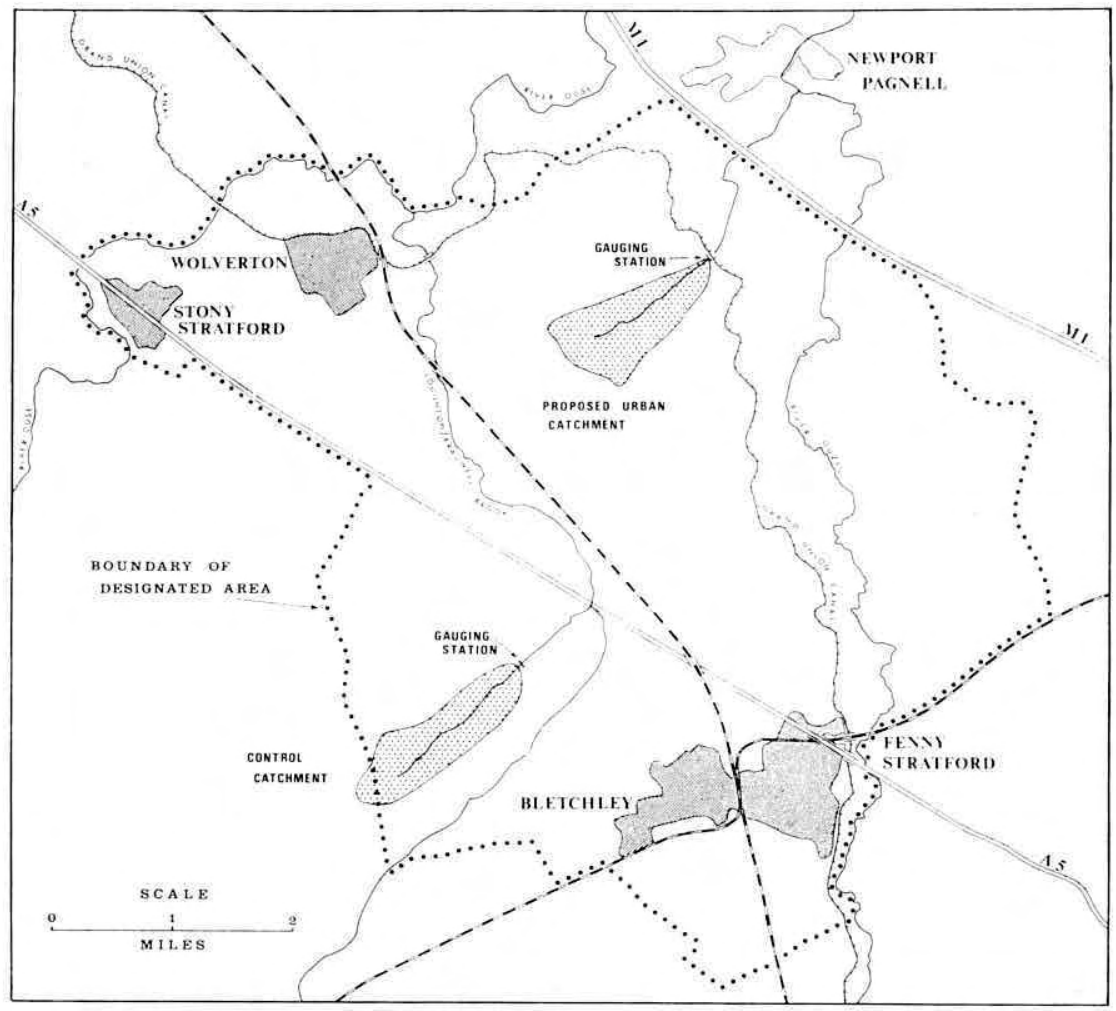

Figure 3 Proposed Milton Keynes catchments within the designated area of the new city

characteristics and types of drainage operations found in this catchment. The first two years of data from the catchment have been successfully processed and an analysis has been made of the rainfall distribution pattern.

\section{Milton Keynes}

Urbanisation, the second type of land use change mentioned above, is perhaps a more drastic one with far reaching effects in many different spheres. A unique opportunity to study its effects is provided by construction of the proposed new city of Milton Keynes in north Buckinghamshire. Plans to establish two small instrumented catchments within the designated area are now well advanced (Fig. 3), with the cooperation of the Great Ouse River Authority and the Milton Keynes Development Corporation. One catchment is on the periphery of the new city and will serve as a stable control during the period of the 


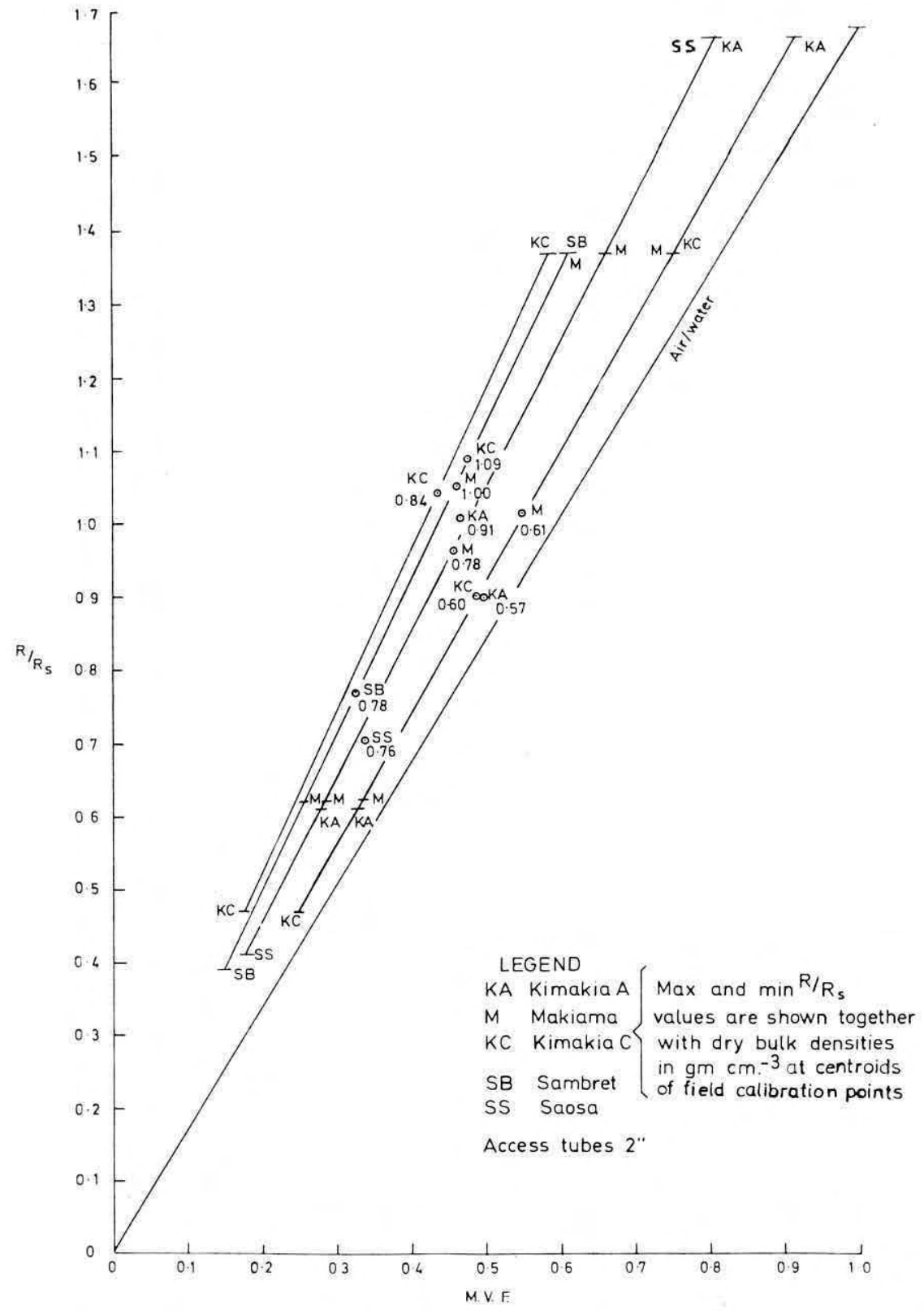

Figure 4 Neutron moisture meter calibration lines for the five catchments in the Kimakia and Kericho areas in Kenya

Moisture volume fraction (M.V.F.) is plotted against count rate ratio (R/Rs) where $R$ is the soil count rate and $R_{s}$ is the count rate in a standard 
experiment. The other is near the centre of the designated area and should be built upon within the next six years. A number of technical points have still to be overcome before work on instrumentation can begin. Nevertheless, it is hoped that the project will be underway by the summer of 1970 following the construction of the river gauging flumes.

Apart from the changes in the pattern of runoff, it is expected that the major effects will be felt in water quality. Initial discussions have been held with the Water Pollution Research Laboratory (Ministry of Technology) to consider the Laboratory's participation in the water quality aspects of the project. Their programme will include the monitoring of certain chemical concentrations in the runoff from the two catchments, both by manual sampling and by continuous automatic sampling.

\section{East African Catchments}

Changes in land use have profound effects where the climate is more extreme, and experimental results from catchments markedly different from those encountered in the United Kingdom provide a stringent test for relationships derived in less extreme climatic conditions. The Institute has been fortunate in being able to capitalise on the long term projects initiated by the East African Agriculture and Forestry Research Organisation in Kenya. By seconding staff and supplying more sophisticated instrumentation for these projects, the Institute has strengthened the scientific programme and enabled automatic data processing methods to be applied to the twelve years of rainfall, flow, evaporation and soil moisture records already available. These data are currently being processed to a form suitable for the application of modelling techniques.

Much of the experimental work in the catchments has been associated with the establishment of networks of soil moisture sampling points in the Kericho and Kimakia catchments and carrying out an intensive programme of field calibration of the neutron moisture meters. The soils involved in the calibrations for each set of catchments are genetically similar. Those in the Kericho catchments are deep friable clays which in one case have a thin upper layer derived from volcanic ash. At Kimakia this type of ash cover has been deposited repeatedly, giving a series of loams above the dark red friable clay of the original land surface. A high clay fraction is present in the upper loam. Over 300 field calibration points have been obtained in these catchment soils, but the analysis of the data was complicated by the errors inherent in the gravimetric soil sampling technique, and some data had to be rejected due to suspected compression of the samples. The gradients and positions of the calibration curves were found to be strongly related to 
soil density (Fig. 4), however it is thought that this effect is partly masked by chemical differences between the soils. The provisional curves enable a preliminary analysis of the routine catchment observations to be made, but further field calibration work is being undertaken at the extremes of the soil moisture cycle to confirm the relationships. 


\section{HYDROLOGICAL MODELS}

\section{WATER BALANCE MODELS}

The first stage in an analysis of hydrological data is to construct a simple water balance model to test the reliability of the data and assess the importance of individual components within the hydrological cycle. Discrepancies in the water balance may be due to accidental and systematic errors in the measurement of the hydrological variables or to omission of important components of the cycle. Detection and elimination of these sources of error enable parametric models to be more realistic in terms of the prototype, and hence make them more useful for purposes other than predicting runoff. For instance, applying a significance test to the effect of additional parameters in the model may point to productive lines of research which could be pursued by the physical hydrologist.

\section{River Ray}

The first water balance has been produced for the River Ray at Grendon Underwood. It has been found that, in this physically simple clay catchment, a water balance model will predict catchment storage to within 5 per cent of the rainfall input (i.e. $\pm 10 \mathrm{~mm}$ ) on a yearly basis. There are seasonal discrepancies of $\pm 30 \mathrm{~mm}$ which can be attributed mainly to the evaporation estimates and in particular to the lack of a soil heat flux component in the evaporation formulae. Estimates of soil heat flux have been made from soil temperature measurements to correct for this source of error.

To refine the water balance further, a more intensive soil moisture network has been established to test the validity of some of the assumptions implicit in the earlier network and to sample woodland areas in more detail.

Tritium profiles taken from the clay have provided some additional information relating to infiltration. Mean annual water recharge to the strata appears to be about $90 \mathrm{~mm} /$ year and a mechanism suggesting that this input occurs in the autumn has been proposed (Smith, Wearn, Richards and Rowe, 1970).

\section{River Cam above Dernford Mill}

Similar water balance data are being collected by the Great Ouse River Authority and the Institute for the Cam catchment around Saffron Walden, Essex. This larger catchment $\left(200 \mathrm{~km}^{2}\right)$ is mainly on chalk, and in addition to the normal hydrological variables, well water levels are being recorded.

The main aim of the project is to develop flow prediction models of a 
catchment with a large groundwater contribution to runoff. In addition, the water balance information will be used in an assessment of the storage coefficient of the chalk, base flow in the stream and the frequency of occurrence of droughts.

\section{Cairngorms}

In keeping with the projects on land use change, the Institute had planned further projects to deal with the effect of snow on the hydrological cycle. Snow may be regarded as a surface reservoir storing large quantities of water which may lead to rapid runoff and flooding. The amount stored is difficult to assess by conventional means and the Cairngorm project was designed to test water balance methods of estimating the water equivalent of the snow pack and its effect as a component of the hydrological cycle.

The site chosen for the project was subsequently found to have unconsolidated detritus to an unknown depth at the proposed gauging site. A geophysical survey, undertaken by a team from the Institute of Geological Sciences, has recently confirmed the unsuitable nature of the site for conventional stream gauging; a report prepared for the Hydrology Committee of the Natural Environment Research Council, set out the problems of continuing the project within its original terms of reference. The feasibility of the project rested on expanding the original aims to include groundwater studies. This would have necessitated much larger expenditure and would have strained the manpower resources of the Institute. Under these circumstances the Hydrology Committee in March 1970 chose to abandon the project.

\section{South Georgia - Antarctica}

The Institute has collaborated with the British Antarctic Survey in planning a glacio-hydrological study in South Georgia. One of the aims of the project will be to establish a water and energy balance in a small corrie glacier. The feasibility of the hydrological parts of the work depends upon gauging the summer melt stream from the glacier. A reconnaissance was made of the mouth of the corrie during the 1969/70 summer season.

\section{MODEL STUDIES FOR FLOW FORECASTING}

The problems inherent in studying the hydrological cycle by means of classical physical experiments under natural conditions are such that understanding even the simplest process may require a long term project. The complexity of the hydrological cycle leads also to problems 
of sampling in space and time and to difficulties in obtaining controlled environmental conditions. It is impossible as yet, for instance, to manipulate rainfall and evaporation outside a laboratory.

One alternative approach is to simulate the hydrological cycle within a drainage basin by means of a conceptual model. This could be a simple correlation between rainfall and runoff or a complex physical synthesis of all the hydrological processes. Usually, a compromise between these approaches is adopted using a number of parameters which may or may not have physical meaning. These parameters are optimised to reduce the difference between predicted and observed runoff (Research 1968, p 43).

A series of papers which describe the development of models for flow forecasting has been prepared. The first (Nash and Sutcliffe, 1970) describes some of the principles which should influence the development of the model, and points to the need for simple models, with parameters which are independent in their effects. Independence is necessary if the parameters are to be optimised with precision. At the same time a systematic approach to the development and testing of the models is required. There should be no unnecessary proliferation of parameters, and each additional part of the model must substantially extend the range of application of the whole model. Objective testing of the effect and stability of additional parameters is essential.

The methods have been applied to the River Brosna at Ferbane, where it was found possible to account for over 80 per cent of the initial variance of discharge by objective fitting of very simple models (O'Connell, Nash and Farrell, 1970).

When these methods were applied to the Ray catchment at Grendon Underwood, it was decided to study separately the portion of the models determining runoff volumes from the routing portion. By dividing the 4 years of record into 204 periods of runoff and causative rainfall, the parameters of two separate soil moisture models were determined. One model represents the basin as a stack of soil layers with equal storage, from which the evaporation decreases as a ratio of the potential rate as successive layers are exhausted; the layers are refilled by rainfall from the top. This model incorporates an immediate runoff factor and a limiting infiltration capacity. The second model comprises areas of grass with a limited root constant together with an area of trees and a riparian area, both of which are assumed to have unlimited storage for evaporation. The areas and root constant are optimised to provide the best fit between estimated and measured runoff volumes. This model can also include an immediate runoff factor and it has been found possible to account for over 90 per cent of the initial variance of runoff volumes. Simple routing 
techniques have been tested with the volume models and these have been used to account for about 75 per cent of the initial variance.

The results of previous studies of recession flows at Grendon Underwood have supported the concept of a variable saturated area which is related to the recession constant of a simple non-linear recession equation. Preliminary results from a non-linear routing of the volume model have shown that such a reservoir is at least as good as two linear reservoirs in parallel. However, variation of the reservoir constant in a simple sinusoidal fashion through the year, as suggested by the results of the recession study, did not produce a significant improvement.

The basic volume model has been modified to allow a variable saturated area dependent primarily on the overall catchment deficit. Trials of this model have shown a significant improvement on previous models despite there being one less parameter required. Routing trials will follow using knowledge of the current catchment state to adjust the reservoir constant.

The effect of using different time periods on the sensitivity and success of a basic model is being tested. To date the data have been used in three hourly periods, but tests will be made using 6,12 and 24 hourly data.

A start is being made on the collection of data from other catchment areas having different characteristics, in order to generalise the model further by the inclusion of such facets as base flow and rainfall interception as appropriate. Data collection on the scale required is time consuming, and meanwhile the models will be adapted for application to the Coal Burn and East African catchments. 